T. I. YUSHINA ${ }^{1}$, Head of Department, Associate Professor, Candidate of Engineering Sciences, yuti62@mail.ru NGUYEN THU THUY ${ }^{1}$, Post-Graduate Student

A. M. DUMOV ${ }^{1}$, Associate Professor, Candidate of Engineering Sciences

NGUYEN VAN TRONG ${ }^{1}$, Probationer

${ }^{1}$ National University of Science and Technolgy - NUST MISIS, Moscow, Russia

\title{
FEATURES OF MATERIAL CONSTITUTION OF QUARTZ-FELDSPAR ORE FROM QUANG NAM DEPOSIT IN VIETNAM
}

Introduction

Feldspar is the name of the largest group of aluminosilicate minerals which occur at the top part of the lithosphere and make around $50 \%$ of the crust mass [1-3]. They are the main constituent element of magmatic rocks, crystallize from magma both in intrusive and effusive rocks, and are present in many pegmatites, in metamorphic and sedimentary rocks. Feldspar is a high-value commercial raw material used in production of glass, ceramics, electrical insulators, abrasives, and as an aggregate in manufacture of plastics, paints and rubber $[4,5]$.

Quality of feldspar is governed by by sodium/potassium ratio. Na-feldspar is preferred in production of glass, while $\mathrm{K}$-feldspar is suitable for ceramics production. Alkaline feldspar with high content of potassium is the most valued commercial material for production of phosphorus, high-voltage electrical insulators and welding electrodes [6].

A major source of high-quality feldspar is granitic pegmatites. The size of pegmatites varies from small lenses from one to a few meters thick to large sheet-like bodies tens meters thick, hundreds meters long and having dip angle from $0^{\circ}$ to $65^{\circ}$ [6-8]. $\mathrm{K}$-feldspar is the principal constuituent of granitic pegmatites, gneiss and metasomatic rocks alongside with mica and quartz [8-10]. Mineralogically, pegmatites can be simple and complex. Simple pegmatites contain quartz, feldspar, biotite, apatite, garnet and monazite. Central zones of complex pegmatites can be composed of various minerals such as muscovite, tourmaline, topaz, garnet, spodumene, scapolite, beryllium, apatite, fluorite, zircon and some rare minerals hardly discovered in in the world [11].

Feldspar raw materials are produced in more than 50 countries in the world, and the leading producers are USA and Italy which also develop international quality standards for feldspar processing for the glass and ceramic industries [12].

The Socialist Republic of Vietnam possesses large feldspar reserves but mostly in weathered and semi-weathered zones of pegmatites which conditions complex material constitution of feldspar raw material and governs diverse lattice architecture in the weathering products of feldspar. Currently in the provinces Phu Tho, Lao Cai, Yen Bai, Quang Nam and
Vung Tau in Vietnam, 20 deposits are explored and operated at an annual rated capacity from 30 to $100 \mathrm{Kt}$. Mining practices mostly use manual or semimanual labor in selective extraction and processing of high-grade feldspar ore with follow-up manual classification of products. Manual classification product quality is extremely low and nouniform, which leads to essential under-extraction of useful minerals, high loss, low production profitability, environment pollution and degradation in many regions of the country. Produced feldspar is a raw material for the glass, ceramics and electrode industries in Vietnam. Percentage of feldspar is around $75-85 \%$ in production of ceramic gaze, around $40 \%$ in production of ceramic plates and around $50 \%$ in sanitary wear production [13]. Vietnam has to import high-quality feldspar from Japan, China, India and other country, and the price of the import feldspar jumps to millions of dollars [13]. The task of the current concern and relevance is to study material constitution and processability of K-feldspar, as well as to develop an efficient integrated processing technology to 

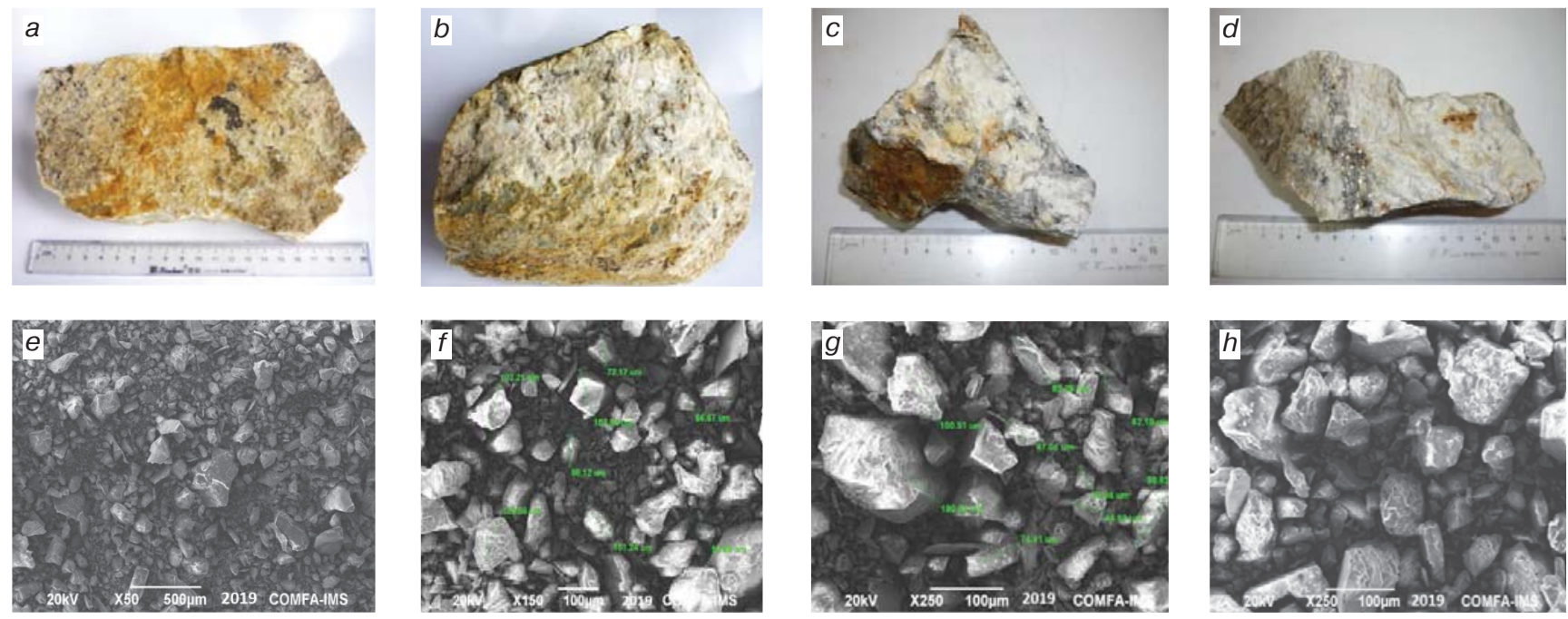

Fig. 1. General view $(a)-(d)$ and microstructure $(e)-(h)$ of quartz-feldspar samples from Quang Nam deposit
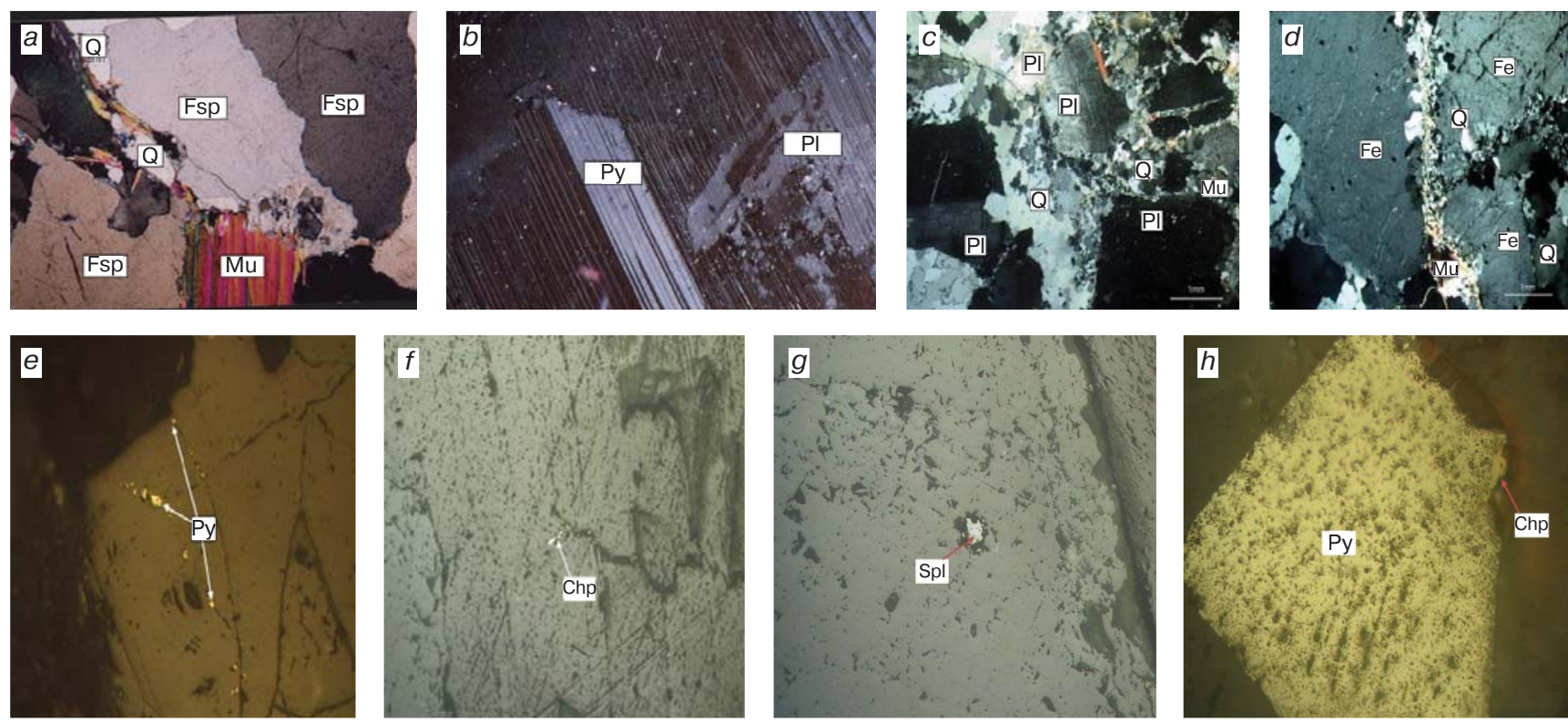

Fig. 2. Microimages of quartz-feldspar ore samples $(a)-(d)$ and sulfide mineral inclusions $(e)-(h)$ in Quang Nam feldspar: $\mathrm{PI}$ - plagioclase; Mu - muscovite; Fsp - K-feldspar; Q - quartz; Py - pyrite; Chp - chalcopyrite; Spl - sphalerite

obtain high-quality product attuned with the market requirements and industry standards, and crucial for import substitution.

The scope of the tests embraced samples of quartz-feldspar ore from Quang Nam deposit in Vietnam.

Material constitution of quartz-feldspar was examined by means of the X-ray diffraction analysis on Bruker's diffractometer D8-Advance; mineralogy and petrography were studied on petrographic microscope Zeiss Axiolab 5. The structural analysis was performed on Scanning electron microscope Quanta 650 and SEM FEG Zeiss Supra ${ }^{\text {tm }}$ 40; the differential thermal analysis was carried out on derivatographic thermoanalyzer MOM Q 1500. Chemistry was analyzed using the method of atomic adsorption and inductive coupled plasma spectrophotometry on plasma spectrometer IRIS-Intrepid II XSP of Thermo Electron Corporation.

\section{Minerographic study and petrographic analysis}

Quang Nam quartz-feldspar ore is a solid mass without pronounced crystal structure, with nonuniform size impregnation with mineral grains from a few tens of microns to a few millimeters in size. The general view and structural features of some representative feldspar samples from Quang Nam deposit are shown in Fig. 1 (images 1-4).

Figures $1 \mathrm{e}-1 \mathrm{~h}$ offer microimages in reflected electons, made on SEM Quanta 650 (Thermo Fisher Scientific). They allow determining shapes and sizes of mineral particles after porcelain ball milling to coarseness less than $200 \mu \mathrm{m}$.

The mineralogical and petrogpahic analyses were performed on petrographic microscope Zeiss Axiolab 5 at the Vietnam Institute of Geosciences and Mineral Resources in Hanoi. Figure 2 offers microimages of polished sections of Quang Nam quartz-feldspar ore samples. 
The optical microscopic analysis makes it possible to draw some conclusions below:

- K-feldspar (orthoclase) $\mathrm{K}\left[\mathrm{AlSi}_{3} \mathrm{O}_{8}\right]$ represents oblique platelike particles $4-10 \mathrm{~mm}$ in size, with handful of extremely fine impurities of mafic minerals and iron oxides;

- plagioclase represents mineral species of continuous homomorphous substitution from albite $\mathrm{Na}\left[\mathrm{AlSi}_{3} \mathrm{O}_{8}\right]$ to anorthite $\mathrm{Ca}\left[\mathrm{Al}_{2} \mathrm{Si}_{2} \mathrm{O}_{8}\right]$. Albite from plagioclase group dominates. Plagioclase represents mainly half-broken platelike particles of irregular shape and 0.9 to $1.7 \mathrm{~mm}$ in size, with surface partly impure with clayey minerals and sericite. The surface forms of plagioclase are very diverse;

- mica (muscovite) $\mathrm{Kal}_{2}\left[\mathrm{AlSi}_{3} \mathrm{O}_{10}\right](\mathrm{OH})_{2}$ is deformed or broken laminas in small aggregates sometimes disseminated as deformed plates and nests in a sample. Mica particles are colorless with lustrous to metal shine;

- quartz $\left(\mathrm{SiO}_{2}\right)$ represents heavily broken crystalls inbetween feldspar particles. Quartz has a clean surface.

The other minerals such as chalcopyrite, sphalerite, sphene and pyrite are sealdom in the ore samples, and occur as small clusters in the joints between feldspar grains. Sometimes colloid limonite is observed in the inter-grain space.

\section{Mineral and chemical analyses}

The X-ray phase analysis of a quartz-feldspar ore sample from Quang Nam deposit was performed on Bruker D8-Advance facility. The test data are presented in Tables 1 and 2. The main minerals are quartz $\mathrm{SiO}_{2}, \mathrm{Na}$-feldspar (albite) $\mathrm{NaAISi}_{3} \mathrm{O}_{8}, \mathrm{P}$-feldspar (orthoclase) $\mathrm{KAISi}_{3} \mathrm{O}_{8}$ and muscovite $\mathrm{KAl}_{2}\left(\mathrm{AlSi}_{3} \mathrm{O}_{10}\right)(\mathrm{OH})_{2}$. The base mineral in the size grade of +2 $\mathrm{mm}$ (yield not higher than $2 \%$ ) is exclusively muscovite, other minerals unfound. The minerals mostly concentrate in the size grade of $-2 \mathrm{~mm}$; percentage of quartz is approximately a third part of the sample mass; muscovite percentage is not higher than $25 \%$, percentage of albite is a little higher (27\%) and is twice as large as P-feldspar (orthoclase) percentage. Thus, the base minerals in the sample are feldspar. The total portion of the other minerals is not higher than $1-2 \%$, and the
Table 1. X-ray diffraction analysis data on Quang Nam quartz-feldspar ore sample

\begin{tabular}{|c|c|c|c|c|c|c|}
\hline \multirow[b]{2}{*}{$\begin{array}{l}\text { Size, } \\
\mathrm{mm}\end{array}$} & \multirow[b]{2}{*}{$\begin{array}{l}\text { Yield } \\
\mathrm{g}, \%\end{array}$} & \multicolumn{5}{|c|}{ Content, \% } \\
\hline & & Muscovite & Albite & Orthoclase & Quartz & $\begin{array}{l}\text { Other } \\
\text { minerals }\end{array}$ \\
\hline+2 & 1,92 & 100 & - & - & - & - \\
\hline$-2+0$ & 98,08 & $24-26$ & $26-28$ & $12-14$ & $29-31$ & $1-2$ \\
\hline Итого & 100,00 & $24-26$ & $26-28$ & $12-14$ & $29-31$ & $1-2$ \\
\hline
\end{tabular}

minerals are mostly represented by particles smaller than 20 $\mu \mathrm{m}$ (Table 2).

The grain size composition of original ore and the distribution of valuable mineral components by size grades is very important in processability studies.

An ore sample was crushed on laboratory crushers to the size of $2 \mathrm{~mm}$. The crushed products were classified into five sizes of $-2+1 ;-1+0.2 ;-0.2+0.074 ;-0.074+0.02$ and $-0.02+0 \mathrm{~mm}$. The yield of the sizes was found, and the contents of $\mathrm{Na}_{2} \mathrm{O}, \mathrm{K}_{2} \mathrm{O}$ and other components were determined.

The data on size distribution of mineral grains are compiled in Table 2. The granulometric and chemical analysis data on the test ore sample are given in Table $\mathbf{3}$ and Fig. $\mathbf{3}$.

The conclusion drawn from the data in Table 3 and Fig. 4 is that the yield and size distribution of useful components are relatively uniform. The mass percentage of fines $-0.02 \mathrm{~mm}$ in size in the test sample is high $-17.29 \%$.

Iron minerals are mostly uniformly distributed in the ore, and their concentration decreases with a decreasing size of particles. The total mass percentages of $\mathrm{K}_{2} \mathrm{O}$ and $\mathrm{Na}_{2} \mathrm{O}$ are almost constant in all narrow-range size grades, and the same pattern is observed for $\mathrm{SiO}_{2}$ and $\mathrm{Al}_{2} \mathrm{O}_{3}$. We come to a conclusion that a product finer than $2 \mathrm{~mm}$ is unextractable in the test material.

The stereomicroscopic analyses of pegmatite samples from the test deposit show that coarse feldspar particles are connected with quartz, mica and iron-bearing minerals.

Table 2. Distribution of mineral particles by size grades in test quartz-feldspar ore sample

\begin{tabular}{|c|c|c|c|c|c|c|}
\hline \multirow{2}{*}{ Size grades, $\mathrm{mm}$} & \multirow{2}{*}{ Yield g, \% } & \multicolumn{5}{|c|}{ Content, \% } \\
\cline { 3 - 7 } & & Muscovite & Albite & Orthoclase & Quartz & Other minerals \\
\hline$-2+1$ & 22.48 & $38-40$ & $16-18$ & $5-7$ & $24-26$ & Low content \\
\hline$-1+0,2$ & 18.32 & $29-31$ & $26-28$ & $12-14$ & $27-29$ & Low content \\
\hline$-0,2+0,074$ & 25.88 & $9-11$ & $26-28$ & $7-9$ & $51-53$ & Low content \\
\hline$-0,074+0,02$ & 16.03 & $7-9$ & $29-31$ & $9-11$ & $48-50$ & Low content \\
\hline$-0,02+0$ & 17.29 & $14-16$ & $29-31$ & $14-16$ & $31-33$ & $1-2$ \\
\hline Total & 100.00 & $24-26$ & $26-28$ & $12-14$ & $29-31$ & 1 \\
\hline
\end{tabular}

Table 3. Chemical analysis results of test sample

\begin{tabular}{|c|c|c|c|c|c|c|c|c|c|c|c|c|}
\hline \multirow{2}{*}{ Size, mm } & \multicolumn{2}{|c|}{ Yield } & \multicolumn{6}{|c|}{ Mass percentage, $\%$} & \multicolumn{4}{|c|}{ Distribution, \% } \\
\hline & $g, \%$ & Total, \% & Igniting loss & $\mathrm{SiO}_{2}$ & $\mathrm{Al}_{2} \mathrm{O}_{3}$ & $\mathrm{Fe}_{2} \mathrm{O}_{3}$ & $\mathrm{~K}_{2} \mathrm{O}$ & $\mathrm{Na}_{2} \mathrm{O}$ & $\mathrm{K}_{2} \mathrm{O}$ & $\mathrm{Na}_{2} \mathrm{O}$ & $\mathrm{K}_{2} \mathrm{O}$ & $\mathrm{Na}_{2} \mathrm{O}$ \\
\hline$-2+1$ & 22,48 & 22,48 & 0,69 & 73,37 & 15,42 & 1,00 & 5,03 & 3,07 & 21,47 & 20,48 & 21,47 & 20,48 \\
\hline$-1+0,2$ & 18,32 & 40,80 & 0,32 & 74,83 & 14,83 & 0,83 & 5,38 & 3,14 & 18,7 & 17,07 & 40,17 & 37,55 \\
\hline$-0,2+0,074$ & 25,88 & 66,68 & 0,25 & 76,92 & 13,08 & 0,64 & 5,11 & 3,49 & 25,09 & 26,8 & 65,26 & 64,35 \\
\hline$-0,074+0,02$ & 6,03 & 82,71 & 0,64 & 76,78 & 13,14 & 0,68 & 5,23 & 3,75 & 15,91 & 17,84 & 81,17 & 82,19 \\
\hline$-0,02+0$ & 17,29 & 100 & 0,34 & 74,34 & 14,61 & 0,57 & 5,74 & 3,47 & 18,83 & 17,81 & 100 & 100 \\
\hline Total & 100 & & 0,44 & 75,27 & 14,20 & 0,75 & 5,27 & 3,37 & 100 & 100 & & \\
\hline
\end{tabular}




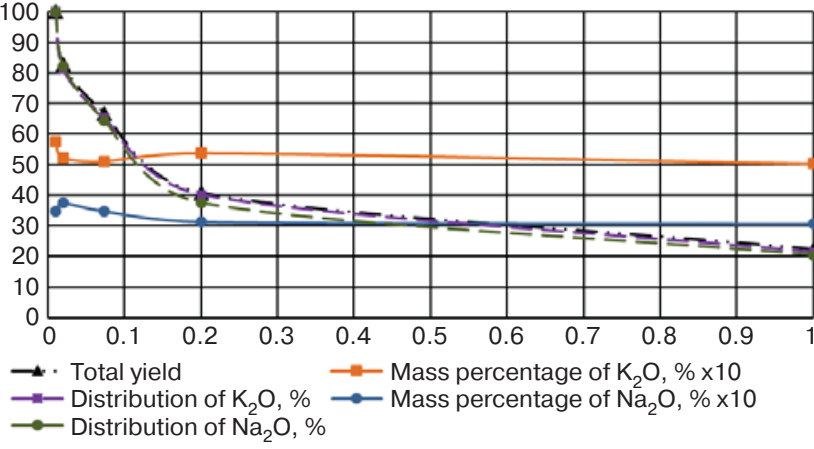

Fig. 3. Screening specification of test sample, content and distribution of $\mathrm{K}_{2} \mathrm{O}$ and $\mathrm{Na}_{2} \mathrm{O}$
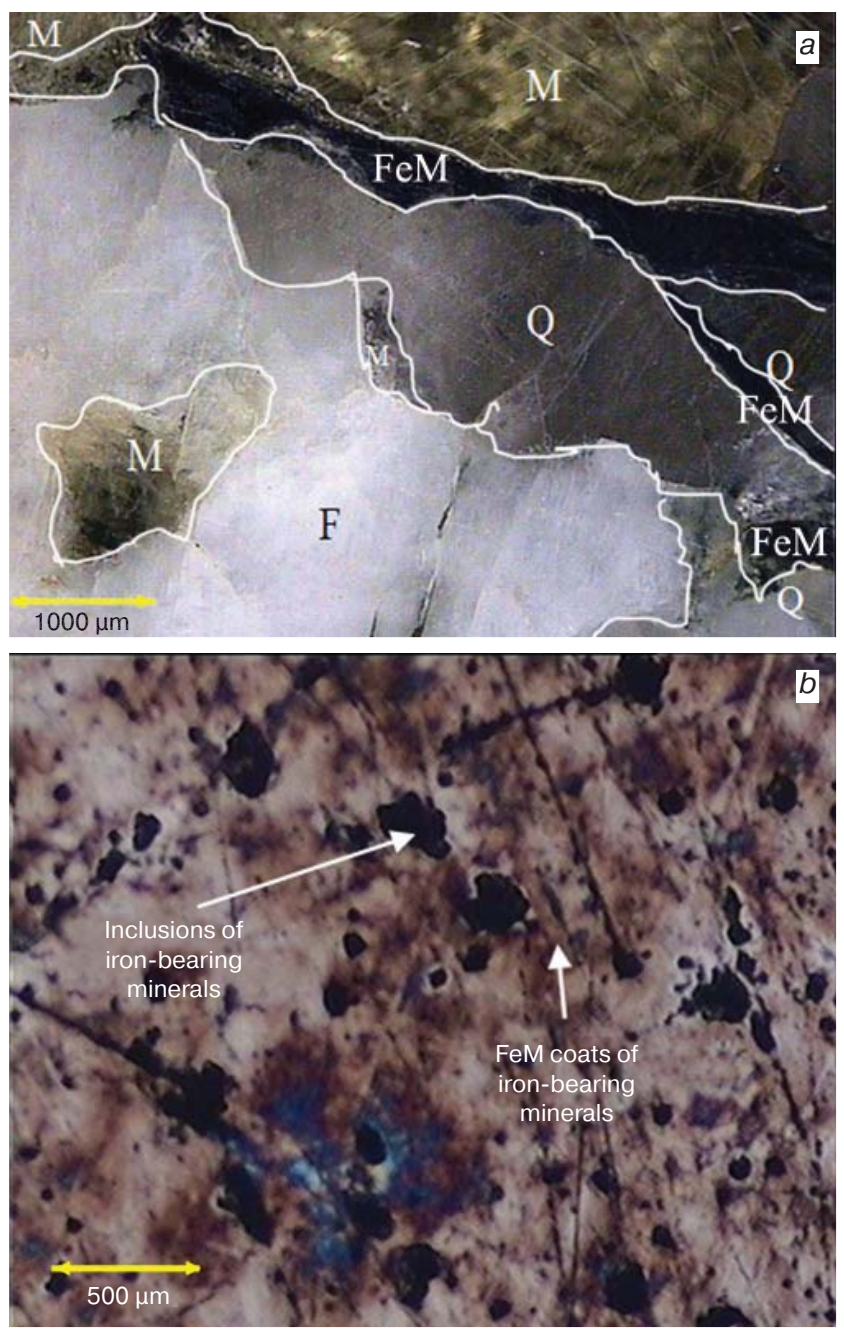

Fig. 4. Polished sections of Quang Nam ore samples:

(a) feldspar $(F)$ connected with quartz $(Q)$, mica $(m)$ and ironberating minerals (FeM); $(b)$ feldspar with coats and inclusions of iron-bearing minerals

Figure 4 shows a typical pegmatite rock sample: some feldspar particles are essentially covered with coats of iron-bearing minerals. Some iron minerals occur as inclusions in feldspar.
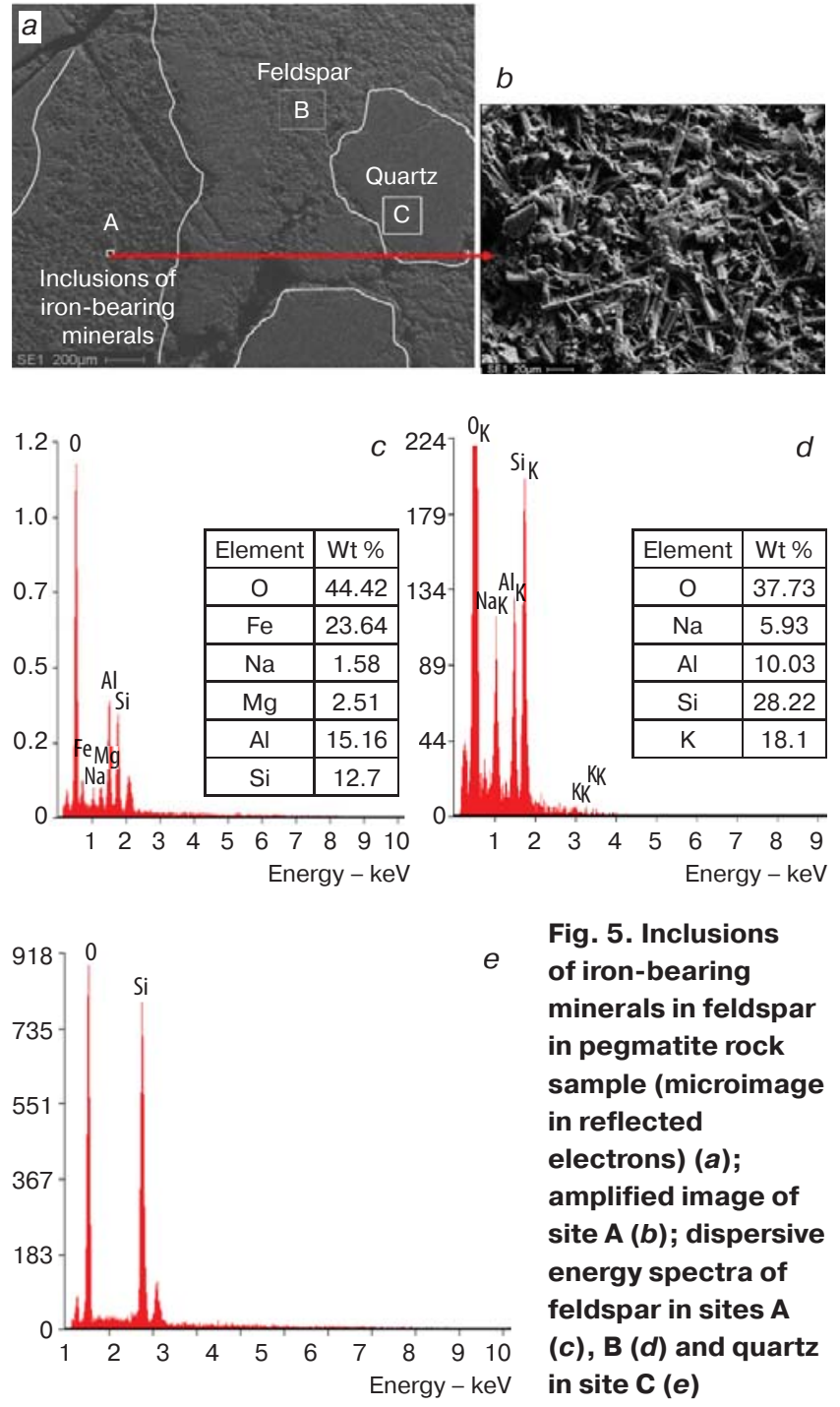

Fig. 5. Inclusions of iron-bearing minerals in feldspar in pegmatite rock sample (microimage in reflected electrons) (a); amplified image of site A (b); dispersive energy spectra of feldspar in sites A (c), B (d) and quartz in site $C(e)$

\section{SEM-based mineralogy analysis on SEM FEG Zeiss Supratm 40}

Figure 5 offers a microimage of pegmatite rock sample surface. Iron is present in inclusions of iron-bearing minerals (Fig. 6a, site A). Site A is amplified in Fig. 6b. The dispersive energy spectrum of site $A$ is demonstrated in Fig. 6c. The spectrum contains: O (44.42\%), Na (1.58\%), Al (15.16\%), $\mathrm{Si}(12.70 \%)$ and $\mathrm{Mg}(2.51 \%)$. The dispersive energy analysis of feldspar in site B also shows O (37.73\%), Na (5.93\%), Al $(10.03 \%)$, Si $(28.22 \%)$ and K (18.10\%). Furthermore, inclusions of quartz are found in site $\mathrm{C}$, which is confirmed in the spectrum in Fig. 6e.

The SEM-based analysis of mica was also carried out on Zeiss Suprat $^{\text {tm }} 40$, in particular, to fine iron on mica surface or in its structure. The mica surface microimage (Fig. 6a) and the image of site $A$ in characteristic iron beams (Fig. 6b) show the presence of: O (42.66\%), Al (21.78\%), Si (22.53\%), $\mathrm{Fe}(3.95 \%)$ and $\mathrm{K}(8.26 \%)$. This proves that the material is muscovite (fits the muscovite formula $\mathrm{KAl}_{2}\left(\mathrm{AlSi}_{3} \mathrm{O}_{10}\right)(\mathrm{OH})_{2}$ ). Iron in muscovite can be in iron mineral coats on muscovite surface. 

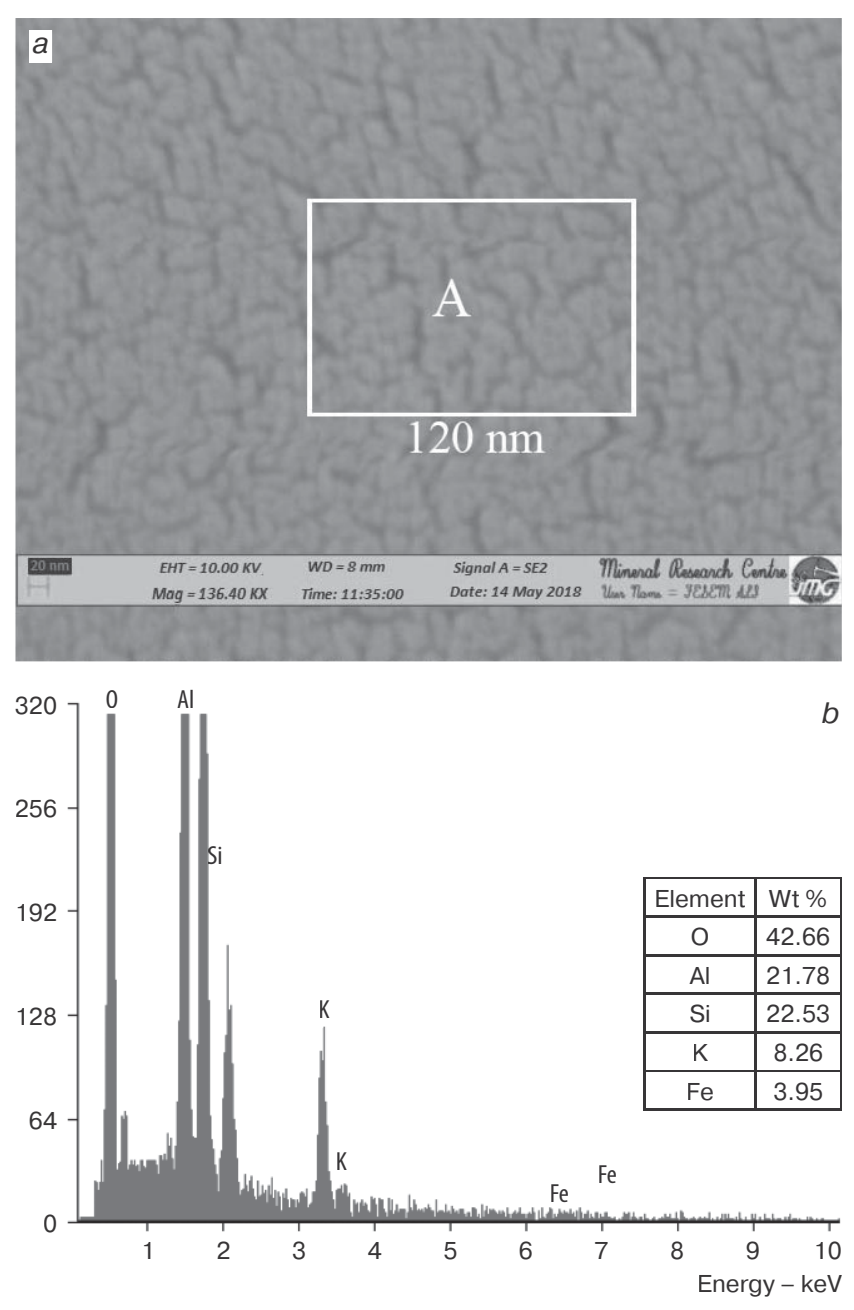

Fig. 6. Surface microimage of mica (muscovite) in backscattered electrons (a); image of site A in characteristic iron beams (b); dispersive energy spectrum of muscovite (site $A$ ) with inclusions of iron (data on contents of $\mathrm{O}, \mathrm{Al}, \mathrm{Si}, \mathrm{K}$ and Fe) (c)

Thus, the studies into material constitution of laboratory quartz-feldspar ore samples from Quang Nam deposit in Vietnam show that:

- the ore ha a relatively complex composition;

- the base minerals are orthoclase, albite, muscovite and quartz.

Alongside with feldspar, the ore contains some associate minerals, including free quartz and mica group minerals, as well as iron-bearing minerals as inclusions and coats in feldspar.

The chemical analysis results show that the chemical composition of ore changes as follows: the mass percentage of $\mathrm{Al}_{2} \mathrm{O}_{3}$ varies from 13.08 to $15.42 \%$ and is one average $14.20 \%$; mass percentage of $\mathrm{Fe}_{2} \mathrm{O}_{3}$ is 0.51 to $1.00 \%$, on average $0.75 \% ; \mathrm{SiO}_{2}-75.27 \%$. The mass percentage of alkali metal oxides is relative equal in different size grades; the total mass percentage of $\left(\mathrm{K}_{2} \mathrm{O}+\mathrm{Na}_{2} \mathrm{O}\right)$ is on average $8.64 \%$.

For high-quality concentration of feldspar, it required to remove mica, quartz and iron-bearing minerals. These minerals have similar physical properties, such as density, conductibility and magnetism. Therefore, gravity, magnetic and electric

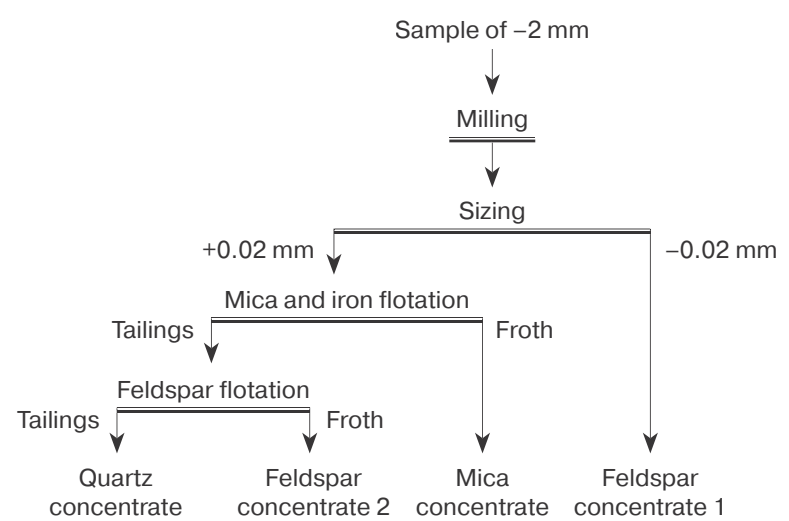

Fig. 7. Processing circuit for quartz-feldspar ore from Quang Nam deposit in Vietnam

separation methods are incapable to ensure total extraction of these impurities from feldspar [14, 15].

The most suitable method to remove mafic mineral impurities, including iron and free quartz, is flotation [16-19]. The flotation flow chart for feldspar ore should contain four stages:

- desliming (removal of clayey minerals);

- flotation of mica group minerals;

- flotation of iron-bearing minerals;

- flotation of feldspar.

The collector in direct flotation of mica and iron-bearing silicates is aromatic amine [15-17]. Flotation is implemented in sulfuric-acid environment at $\mathrm{pH}=3-3.5$. The mica flotation middlings are washed, and $\mathrm{pH}$ is reduced to $2.5-3$ using hydrofluoric acid which activates feldspar and depresses silica. Flotation of feldspar uses a cation collector. The feldspar flotation tailings (middlings) represent a high-quality quartz concentrate.

The key objective of Quang Nam ore processing is removal of mica, quartz and iron-bearing minerals from it. It is possible to enhance flotation efficiency and reduce consumption of reagents by including selective milling in the ore treatment circuit. In this case, ore particles mainly break along the boundaries between mineral grains and in grains of easily grindable minerals. The proposed processing circuit includes crushing of ore to the size of $10 \mathrm{~mm}$ on a jaw crusher and then on a roll crusher with roll spacing of $2 \mathrm{~mm}$. Screening of $2 \mathrm{~mm}$ size provides processing by particle shape. Flat mica particles go to oversize fraction and make a mica concentrate at the yield of $1.92 \%$ and mica mass fraction of $100 \%$. In order to reduce impact of slime on flotation, it is required to remove material with the size of $-0.02+0 \mathrm{~mm}$ and with some muscovite content [4]. The comparison of the chemical and mineralogical analyses data on the material of $-0.02 \mathrm{~mm}$ size with the quality standard of feldspar used in building ceramic production (standard TCVN 6598:2000) shows that the test material is suitable for manufacture of ceramic goods and ceramic tiles.

The proposed processing circuit for quartz-feldspar ore from Quang Nam deposit in Vietnam is presented in Fig. 7.

\section{Conclusions}

From the evidence of the integrated studies into material constitution of quartz-feldspar ore from Quang Nam deposit in Vietnam, some conclusions are drawn and listed below. 
1. Quang Nam quartz-feldspar ore is a dense solid without pronounced crystalline structure and nonuniform coarseness of dissemination with mineral grains from a few tens of microns to a few millimeters in size.

2. The ore features a comparatively complex mineral composition. The main useful mineral is feldspar (orthoclase and albite). The ore also contains free quartz, mica group minerals (muscovite) and iron-bearing minerals as inclusions and coats in feldspar. The mass percentage of $\mathrm{Al}_{2} \mathrm{O}_{3}$ is on average $14.20 \% ; \mathrm{Fe}_{2} \mathrm{O}_{3}-0.75 \% ; \mathrm{SiO}_{2}-75.27 \%$. The total percentage of alkali metals $\left(\mathrm{K}_{2} \mathrm{O}+\mathrm{Na}_{2} \mathrm{O}\right)$ in different size grades is approximately the same $-8.64 \%$.

3. For the production of high-quality feldspar concentrates, it is required to remove mica, quartz and iron-bearing minerals. Considering similar physical properties (magnetic, electric, density) of the separated minerals, as well as the size of the inclusions, the most efficient and selective method of feldspar separation from free quartz, mica and mafic mineral impurities is flotation. The propose circuit of quartz-feldspar flotation includes desliming (removal of clayey minerals), and flotation stages for mica group minerals, iron-bearing minerals and feldspar.

4. Feldspar flotation uses cation collectors (amines) in strongly acid environment, after pull treatment by hydrofluoric acid to depress quartz and activate flotation of feldspar.

5 . In order to stimulate flotation and reduce consumption of reagents in ore pretreatment, it recommended using selective milling and subsequent size screening by the size of $2 \mathrm{~mm}$ to separate particles by shape. Flat mica particles to oversize fraction and make a mica concentrate with the yield of $19.2 \%$ and mica mass percentage of $100 \%$. Aimed to avoid impact of slime on flotation, it is required to remove material $-0.02+0 \mathrm{~mm}$ in size, with some content of muscovite. The comparison of the chemical and mineralogical analyses data on the material of $-0.02 \mathrm{~mm}$ size with the quality standard of feldspar used in building ceramic production (standard TCVN 6598:2000) shows that the test material is suitable for manufacture of ceramic goods and ceramic tiles. Thus, the studies into material constitution show that Quang Nam quartz-feldspar ore can be processed toward production of commercial value products in high demand in many industries.

References

1. Eremin N. I. Nonmetal minerals. Moscow : MGU, 1991.

2. Russian Geological Encyclopedia. 3 volumes. Moscow-SaintPetersburg : VSEGEI, 2011. Vol. 2. 704 p.

3. Sun G., Wang M., Guo J., Wang Y., Yang Y. Geochemical Significance of Clay Minerals and Elements in Paleogene Sandstones in the Center of the Northern Margin of the Qaidam Basin, China. Minerals. 2020. Vol. 10(6). pp. 505.

4. Zhang Y., Hu Y., Sun N., Liu R., Wang Z., Wang L., Sun W. Systematic review of feldspar beneficiation and its compre- hensive application. Minerals Engineering. 2018. Vol. 128. pp. 141-152.

5. Ghalayini Z. T. Feldspar and nepheline syenite. Minerals Yearbook-2017. U. S. Geological Survey, 2020. 24 p.

6. Bates R. L. Geology of the Industrial Rocks and Minerals. New York : Dover Publications, 1969. 459 p.

7. Pegmatitic textures, Pittsburg, Department of Geology \& Planetary. Science School of Arts and Sciences University of Pittsburgh, 2008

8. McLean A. C. Geologi untuk jurutera awam. Universiti Teknologi Malaysia, Skudai, 1998.

9. Bandini P., Prestidge C.A., Ralston J. Colloidal Iron Oxide Slime Coatings and Galena Particle Flotation. Minerals Engineering 2001. Vol. 14(5). pp. 487-497.

10. Deer W. A., Howie R. A., Zussman, J. Rock-Forming Minerals. Vol. 4B. Framework Silicates: Silica Minerals. Feldspathoids and the Zeolites. 2nd ed. London Bath : Geological Society, 2004. 982 p.

11. Gwalani L. G., Dalal V. P., Fernandez S. S., Mulai B. P., Parveen S. et al. Granitic pegmatites of koradi-kolar sector, Ngapur District, Central India: Field of petrographic and mineralogical features. Revista Brasileira de Geociências. 1999. Vol. 29(1). pp. 99-104.

12. Mineral Commodity Summaries. 2020. Available at: https:// pubs.usgs.gov/periodicals/mcs $2020 /$ mcs2020.pdf (accessed: 15.06.2021).

13. Nguyen Van Hanh et al. Research on feldspar processing technology of Mo Ngot, Phu Tho. Mineral Processing and Utilization Science and Technology Center, Vietnam Mineral Association for Mineral Processing. 2006.

14. Hacifazlioglu H., Kursun I., Terzi M. Beneficiation of low-grade feldspar ore using cyclojet flotation cell, conventıonal cell and magnetıc separator. Physicochemical Problems of Mineral Processing. 2012. Vol. 48(2). pp. 381-392.

15. Gülgönül I., Karagüzel C. M., Çelik M. S. Surface vs. Bulk analyses of various feldspars and their significance to flotation. International Journal of Mineral Processing. 2008. Vol. 86, Iss. $1-4$. pp. 68-74.

16. Vidyadhar A., Rao K. H., Forssberg K. S. E. Adsorption of $\mathrm{n}$-tallow 1,3 propanediamine-dioleate collector on albite and quartz minerals and selective flotation of albite from Greek Stefania feldspar ore. Journal of Colloid and Interface Science. 2002. Vol. 248(1). pp. 19-29.

17. Vidyadhar A., Rao Hanumantha K. Adsorption mechanism of mixed cationic/anionic collectors in feldspar-quartz flotation system. Journal of Colloid and Interface Science. 2007. Vol. 306, Iss. 2. pp. 195-204.

18. El-Dine W. N., El-Shershaby A., Afifi S., Sroor A., Samir E. Natural radioactivity and rare earth elements in feldspar samples, Central Eastern desert, Egypt. Applied Radiation and Isotopes. 2011. Vol. 69, Iss. 5. pp. 803-807.

19. Yu Y., Ma L., Cao M., Liu Q. Slime coatings in froth flotation: A review. Minerals Engineering. 2017. Vol. 114. pp. 26-36. EM

\section{ERRATUM}

Erratum to "Mineral Composition and Commercial Application Feasibility of Sericite Ore in Ha Tinh Province" in Eurasian Mining Journal No. 2, 2020 (p. 32). In the published version there is an error in the spelling of the names of the co-authors (Yushina T. I., Dumov A. M., Nguyen Van Chon, Nguyen Thu Thuy). The present form in this erratum is correct: Yushina T. I., Dumov A. M., Nguyen Van Trong, Nguyen Thu Thuy. 